\title{
VRTLINA - GOLEMA ŠPILJA VELEBITSKOG PODGORJA
}

Vlado Božić

Braće Cvijić 17

HR 10000 Zagreb
UDK: 551.435.82(497.5)(234 Velebit)

Stručni članak

Ur.: 2016-12-28

Na krajnjem jugu velebitskog Podgorja, između Visočice i Kruščice, na području PP Velebit, nalazi se špilja s četiri jamska ulaza. Od glavnog, najvećeg ulaznog otvora (veličine 40 × 50 m), koji čini jama duboka sedamdesetak metara, špilja se pruža u smjeru sjeverozapada, gotovo pravocrtno, u duljini 900 m i dubine 195 m. Šrina špiljskog kanala je 20 - 80 m što je čini posebno zanimljivom. Prvi ju je istražio, opisao te izradio njezin nacrt Senjanin Ivan Krajač 1932., a nastavili speleolozi iz Zagreba. U istraživanju Velebita 1961. zagrebački su speleolozi ponovno istražili špilju i topografski ju snimili. Jedno samostalno istraživanje obavio je Jerko Malinar (SO PDS Velebit iz Zagreba) 1978. i negdje pri kraju špilje pronašao novi kanal sa sifonskim jezerom, ali ga nije snimio. Ekipa zagrebačkih speleologa posjetila je Vrtlinu 2000. god. radi fotografiranja, i usput tražila nove dijelove, ali Malinarov kanal nije pronašla. Zadarski planinar Slavko Tomerlin 1987. ugradio je (uz pomoć speleologa) čeličnu sajlu za pridržavanje kod silaza niz strmu stijenu ulazne jame, duboke četrdesetak metara (do vrha sipara). Špilju su posjećivali i planinari i speleolozi, a zadnjih godina mnogo puta i biospeleolozi, proučavajući floru ulaznog dijela špilje i faunu njezine unutrašnjosti. Najveća zanimljivost špilje su golemi podzemni prostori s golemim kamenim blokovima palim sa stropa, ali i prekrasni špiljski ukrasi (saljevi, stalagmiti i stalaktiti u raznim bojama, te ekscentrične sige s velikim vidljivim kristalima). Još je 1932. Ivan Krajač predlagao špilju za turističko uređenje, što je prijedlog i danas, kada za to postoje mnogo veće tehničke mogućnosti.

Ključne riječi: Podgorje, špilja, istraživanje, prostornost, turizam

U Parku prirode Velebit, na njegovu južnom dijelu, između Visočice i Kruščice, na oko 900 m nadmorske visine, nalazi se golema špilja s četiri jamska ulaza. Iako je špilja poznata još od 1932. godine (prvi tekst o špilji) i istraživana od tada više puta, sve njezine tajne još uvijek nisu otkrivene. Svrha članka je prikazati zanimljivosti ove jedinstvene špilje u Hrvatskoj i potaknuti njezino daljnje istraživanje. Također, želja je predstaviti špilju javnosti zbog velikog turističkog potencijala, te se dogovoriti o mogućnosti lakšeg pristupa i turističkog korištenja. 


\section{Dosadašnja saznanja o špilji}

Prvi tekst o ovoj špilji napisao je još 1932. planinar i političar Ivan Krajač. Tada je prikazao njezin detaljni opis i nacrt, ali nije objavio mjesto ulaza u špilju, jer ju je najprije želio urediti za turističko posjećivanje. ${ }^{1}$

Ponukani Krajačevim opisom špilje mnogi su je planinari tražili po Velebitu i, naravno, otkrili njezin ulaz, ali o tome nisu pisali. Položaj ulaza saznali su 1961. zagrebački speleolozi članovi Speleološkog odsjeka Planinarskog društva "Željezničar" i organizirali istraživanje. U višednevnom istraživanju obavljeno je topografsko i fotografsko snimanje špilje. Pristup do špilje opisan je šturo, i to s ličke strane, iz Medka. ${ }^{2}$

Malo detaljniji opis položaja špilje dao je 1981. Željko Poljak u planinarskom vodiču po Velebitu, opisujući uzdužnu stazu po primorskoj trasi Stap - Malo i Veliko Rujno. ${ }^{3}$

Špilju su počeli sve više posjećivati planinari pa je zadarski planinar Slavko Tomerlin 1987., za lakši silaz u špilju, uz pomoć zadarskih planinara i zagrebačkih speleologa, ugradio čelične klinove i sajlu po južnoj, strmoj padini ulazne jame. ${ }^{4}$

Dubina od 195 m, koju je izmjerio Ivan Krajač 1932. i Ivica Posarić 1961. bila je najveća dubina do koje su se tada spustili hrvatski speleolozi u Hrvatskoj, pa je Vlado Božić 1991. i 1998. pisao o tome kao tadašnjem hrvatskom dubinskom rekordu. ${ }^{5}$

Kako se špilja nalazi uz "uzdužnu stazu po primorskoj padini", na dionici Stap - Rujno, o prilazu špilji opet je pisao Željko Poljak u planinarskim vodičima, te dao skicu putova i procjenu vremena hodanja po pojedinim dionicama staza oko Vrtline. ${ }^{6}$

Grupa zagrebačkih speleologa posjetila je Vrtlinu 2000. godine. Dio ekipe tražio je daljnje dijelove špilje (nažalost bezuspješno), dio istraživao floru i tlo špilje, a dio je fotografirao. ${ }^{7}$

U knjizi "Speleologija u Hrvatskoj" Vlado Božić je napomenuo da se Ivan Krajač u Vrtlini spustio 180 m duboko, a njegov pomagač Mile Sjauš 195 m. ${ }^{8}$

\footnotetext{
${ }^{1}$ I. KRAJAČ, 1932, 268-278.

${ }^{2}$ D. PAVLIČEVIĆ, 1961, 61-63.

${ }^{3}$ Ž. POLJAK, 1981, 423.

${ }^{4}$ S. TOMERLIN, 1987, 43.

${ }^{5}$ V. BOŽIĆ, 1991, 72; V. BOŽIĆ, 1998, 155.

${ }^{6}$ Ž. POLJAK, 1998, 401; Ž. POLJAK, 2001, 456.

${ }^{7}$ M. BOMBARDELLI, 2001, 78-79.

${ }^{8}$ V. BOŽIĆ, 2003, 28-29.
} 


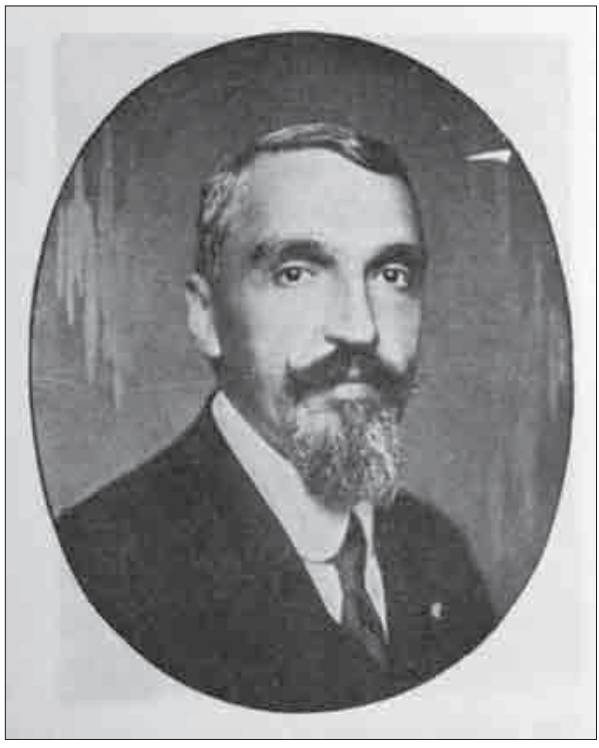

S1. 1. Ivan Krajač, prvi istraživač špilje Vrtline

O prilazu špilji Vrtlini s uzdužne velebitske staze pisao je 2008. Alan Čaplar u svom planinarskom vodiču i naveo da je put (odvojak od staze) zarastao, jer se slabo koristi. $^{9}$

Domogavši se dijela planinarske ostavštine pokojne Hele Krajač, supruge Ivana Krajača također planinarke, Vladimir Jagarić je dobio do tada nepoznatu fotografiju ulaznog dijela špilje Vrtline i objavio ju uz detaljan opis života i rada Ivana Krajača. ${ }^{10}$

U međuvremenu hrvatski su biospeleolozi obilazili hrvatske špilje i određivali koja se špilja može smatrati tipskim lokalitetom špiljske faune. Među takve uvrstili su i špilju Vrtlinu. Do sada su ustanovili da u špilji žive tri tipične špiljske životinje. ${ }^{11}$

Bračni par Mirjana i Boris Vrbek, sudionici spomenutog istraživanja 2000., objavili su 2010. poster o rezultatima florističkih i pedoloških istraživanja. ${ }^{12}$

Pišući 2013. o razvoju speleološke opreme i tehnike u Hrvatskoj, Hrvoje Malinar je opisao svoje spuštanje niz strmu ulaznu jamu u špilju Vrtlinu, ostvareno 1959. bez ikakve opreme. Naveo je također da je njegov brat Jerko Malinar 1978. negdje na kraju špilje našao 15-metarsku jamu s malim sifonskim jezerom. Nažalost o tim događajima nije pisano ranije. ${ }^{13}$

Zadnji objavljeni tekst u kojem se spominje špilja Vrtlina objavljen je 2014., i to u knjizi "Ilustrirana povijest speleologije u Hrvatskoj" Vlade Božića. ${ }^{14}$

${ }^{9}$ A. ČAPLAR, 2008, 512.

${ }^{10}$ V. JAGARIĆ, 2009, 159-160.

${ }^{11}$ B. JALŽIĆ et al., 2010, 225-227, 249.

${ }^{12}$ M. VRBEK - B. VRBEK, 2010, 138 i poster.

${ }^{13}$ V. BOŽIĆ - H. MALINAR, 2013, 56-58.

${ }^{14}$ V. BOŽIĆ, 2014, 35-36. 


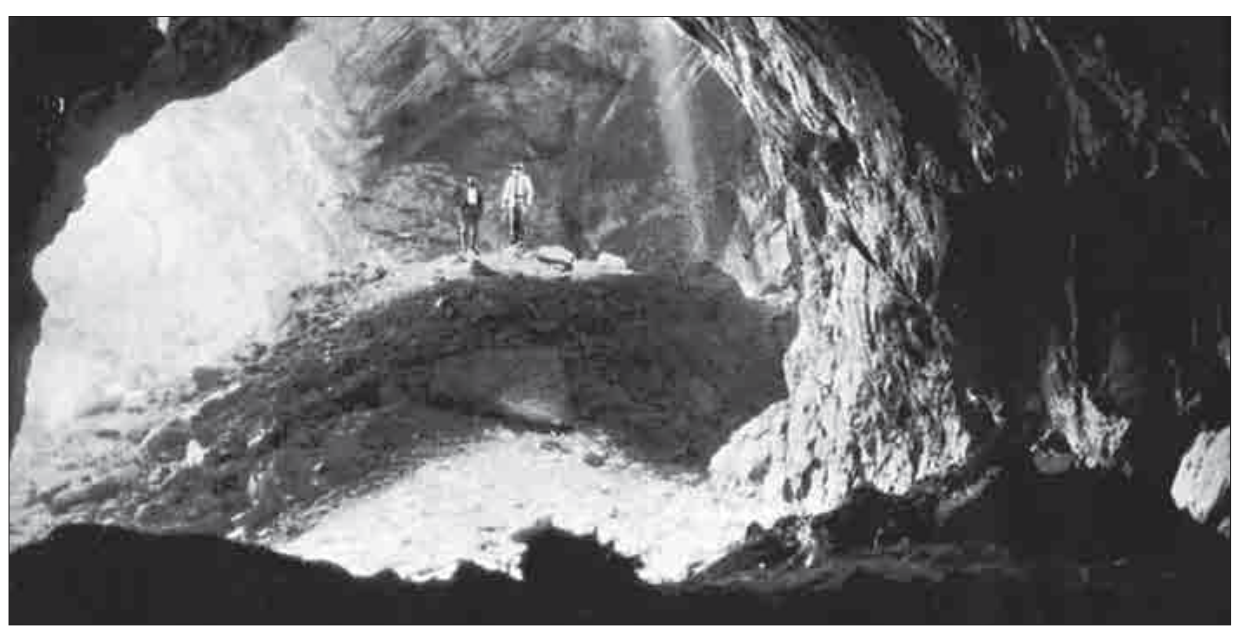

S1. 2. Dno ulazne vrtače špilje Vrtline, foto: I. Krajač, 1932.

\section{Položaj i pristup}

Špilja Vrtlina nalazi se na južnom Velebitu, približno na pola udaljenosti između vrha Visočice $(1615 \mathrm{~m})$ i naselja Kruščice $(0 \mathrm{~m})$ na moru, na nadmorskoj visini od 900 m, između Stapa i Malog Rujna. Od najbližih istaknutijih vrhova udaljena je oko $250 \mathrm{~m}$ sjeverno od vrha Vlaka $(972 \mathrm{~m})$ i oko $750 \mathrm{~m}$ jugozapadno od vrha Sarajevo $(1075 \mathrm{~m})$. Vrtlina je označena topografskim znakom za špilje na topografskoj karti mjerila 1: 25.000 Velika Paklenica br. 469-2-4, a također topografskim znakom i tekstom Špilja Vrtlina na planinarskoj karti PAKLENICA, u mjerilu $1: 25.000$. pa se mogu odrediti i njezine koordinate: 5528350 E, 4916340 $\mathrm{N}, \mathrm{Z}=900 \mathrm{~m}$ (provjereno i GPS-om). Zračna udaljenost od Kruščice do špilje Vrtline, u smjeru sjeveroistoka, iznosi svega $5 \mathrm{~km}$, ali je visinska razlika $900 \mathrm{~m}$.

Pristup do špilje danas je najlakši s juga, tj. od naselja Kruščice do kojeg se može doći Jadranskom magistralom iz smjera Starigrad Paklenice ili iz smjera Karlobaga. Iz Kruščice vodi zavojita, asfaltirana cesta prema sjeveru do zaselka Ljubotić, na nadmorskoj visini od oko $300 \mathrm{~m}$. Tu se može kampirati, ostaviti auto i krenuti dalje pješice. No, postoji i makadamska cesta, odvaja se od asfalta oko $250 \mathrm{~m}$ ispred Ljubotića u lijevo (na zapad) i vodi do Vukićevih mirila (oko $1,5 \mathrm{~km}$ ), gdje treba skrenuti u desno (sjeveroistok) i zavojitom cestom do zaselka Renjevac, koje se nalazi na oko $420 \mathrm{~m}$ n.v.

Od Ljubotića vodi markirana planinarska staza najprije na sjever do Renjevačkih mirila, a odatle na sjeveroistok do Renjevca. Staza se dalje nastavlja u smjeru sjeveroistoka preko šume do velike livade Bili sinokos (oko 750 m n.v.) i 


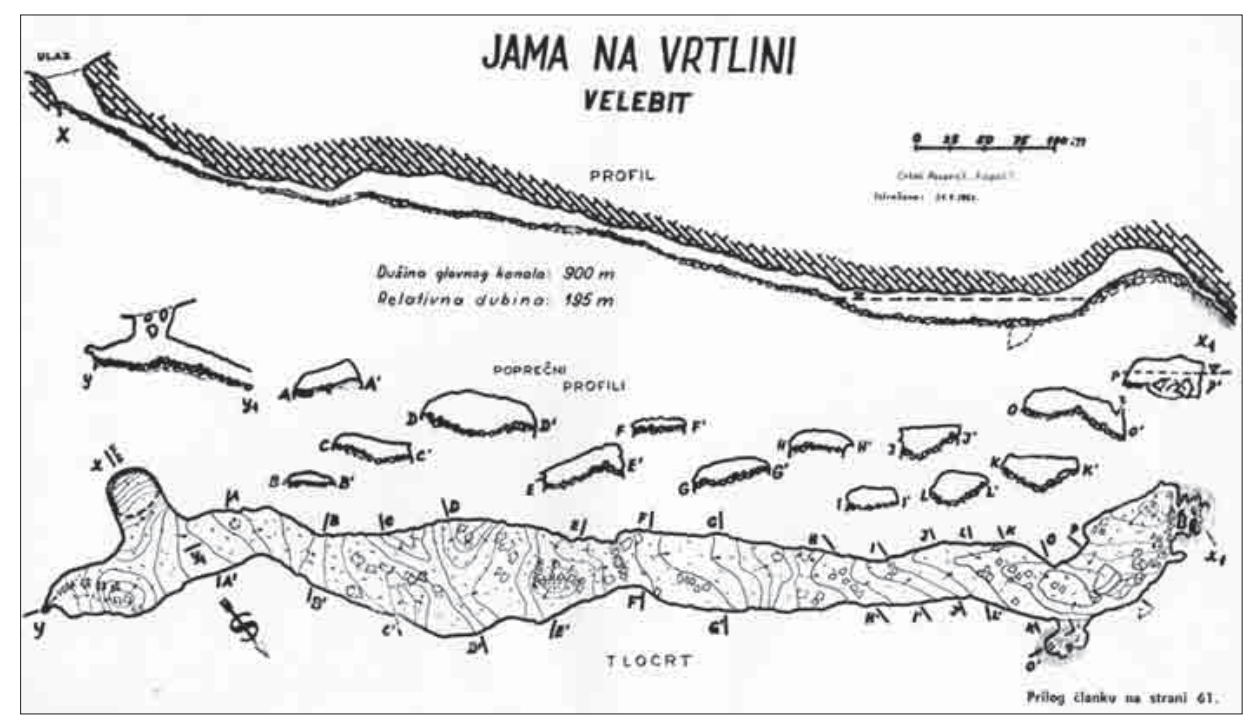

S1. 3. Nacrt špilje Vrtline iz 1961. godine, crtali: Ivica Posarić i Ivan Filipčić

dalje u istom smjeru kroz šumu do livade ispred špilje Vrtline. Dionica preko Bilog sinokosa do Vrtline slabo je označena. Došavši na livadu treba nastaviti dalje do dobro označene planinarske staze u smjeru istoka, koja prolazi iznad špilje i vijuga između jamskih otvora špilje. Svega nekoliko metara od staze, koja prolazi kroz jedna prirodna vrata, nalaze se tri manja otvora, a veći, glavni, nalazi se južno od staze. Do njega vodi jedva vidljiva stazica, i to do njegova južnog ruba.

Do špilje se može doći i planinarskom stazom Veliko i Malo Rujno Stap, odnosno Tatekovo sklonište na Stapu, ili obrnuto od Stapa prema Rujnu. Svakako treba koristiti planinarske karte ovog dijela Velebita.

\section{Opis špilje}

Najlakši silaz u špilju je niz veliki jamski otvor promjera 40 x 50 metara, i to po njegovu jugoistočnom rubu, gdje je Slavko Tomerlin - Tatek postavio klinove i sajle, za koje se treba pridržavati, i koji usmjeravaju silaz. Taj južni dio jame je strm, dok su istočni i zapadni djelovi jame potpuno okomiti, a sjeverni je prevjesni. Četrdesetak metara ispod južnog ruba jame nalazi se vrh sipara kojim se prema sjeveru silazi u prvu veliku dvoranu špilje, osvijetljenu danjim svjetlom. Tu je dvoranu Ivan Krajač nazvao Bagova dvorana a veličine je 50 x 70 m, prekrivena većim i manjim kamenjem palim sa stropa. Južna, strma padina 


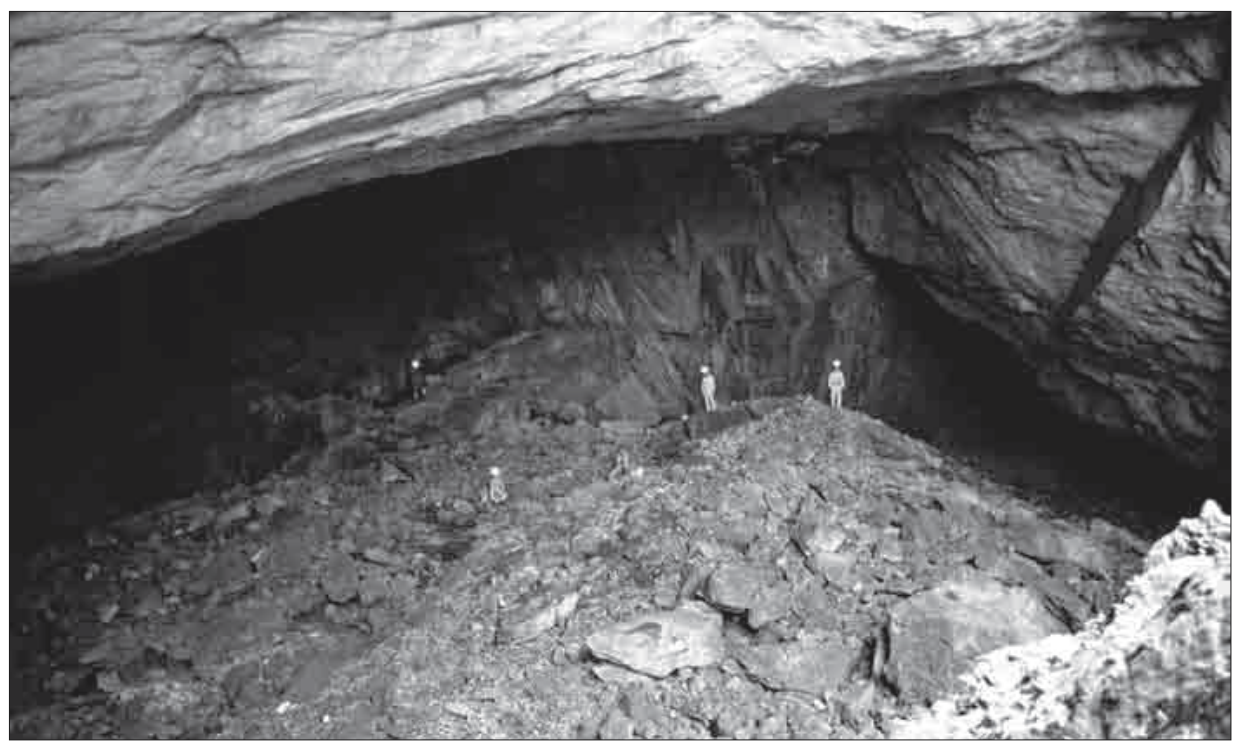

Sl. 4. Dvorana ispod ulazne vrtače - Bagova dvorana, foto: Vlado Božić, 2000.

ulazne jame obrasla je grmljem, kojega ima i u gornjem dijelu sipara. Cijeli je sipar obrastao zelenjem, jer danje svjetlo prodire duboko u špilju.

Sa dna Bagove dvorane u stropu se vide tri otvora. Silaz kroz te otvore moguć je jedino s pomoću speleološke opreme. Dubina od tih otvora do dna dvorane je $70 \mathrm{~m}$. Odvojak u desno, na istok, dug sedamdesetak metara, vodi u Vidov hram ili Kapelicu, gdje se, već u potpunom mraku, u kamenici nalazi voda (treba se malo popeti do nje).

Iz Bagove dvorane špilja se dalje nastvalja u smjeru sjeverozapada, a tlo se blago spušta. Tu se gubi danje svjetlo i počinje potpuni mrak. Krajač je to mjesto nazvao Ždrijelo strave jer se tu širina kanala smanji na "svega" tridesetak metara a strop se snizi na oko tri metra.

Iza Ždrijela strave špiljski se kanal širi i tvori dvoranu široku oko $50 \mathrm{~m} \mathrm{i}$ visoku oko 5 m. Krajač je to mjesto nazvao Babina dvorana.

Nastavljajući dalje u smjeru sjeverozapada ulazi se u najveću dvoranu špilje (Krajač ju je nazvao Krakova dvorana). Zapravo to je samo veliko proširenje špiljskog kanala, udaljeno od ulaza (ili Kapelice) oko 300 m. Širina kanala ovdje je osamdesetak metara, a visina oko 25 metara. Tlo, koje se u nastavku stalno lagano spušta, kao i u prethodnoj dvorani, predočeno je golemim kamenim blokovima po kojima kaplje voda pa su mjestimično nastali razni sigasti ukrasi - stalagmiti u bijeloj i žutoj boji. 


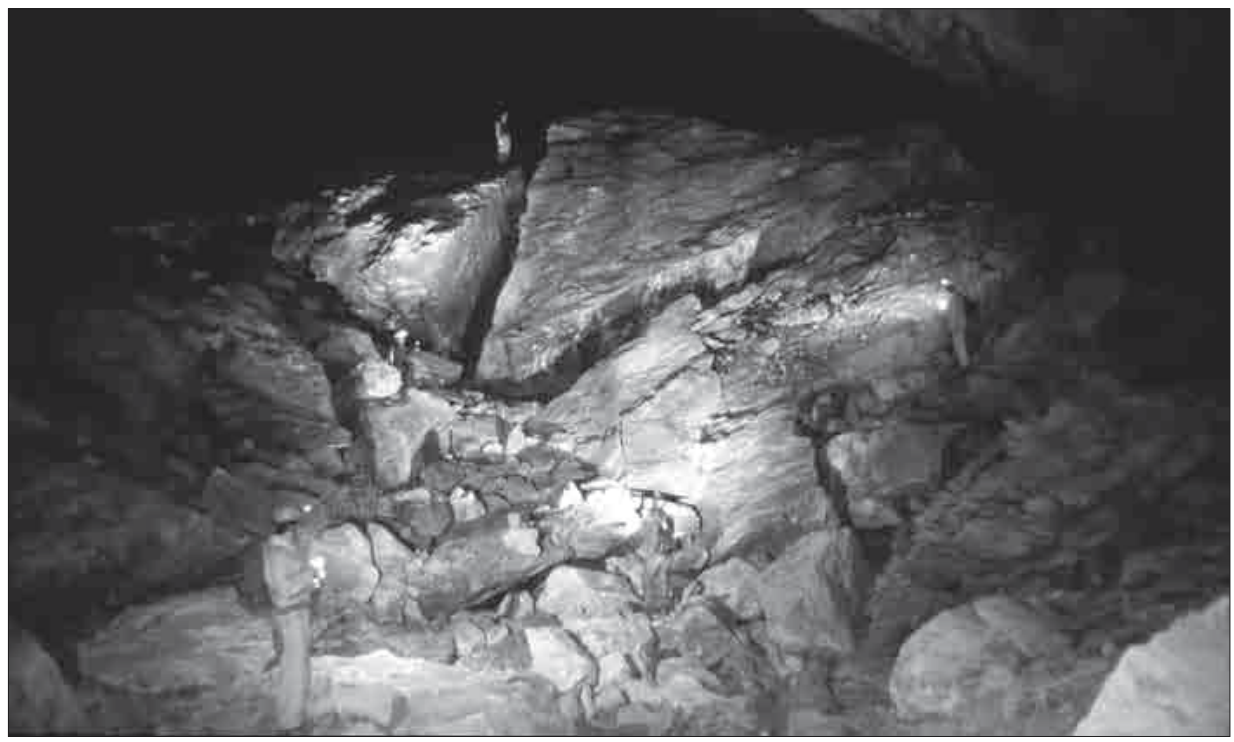

S1. 5. Šnita kamene torte - dvorana Crne kraljice, foto: Vlado Božić, 2000.

U nastavku se širina kanala smanjuje na $35 \mathrm{~m}$ i visina na oko $5 \mathrm{~m}$. Tu se u dnu kanala vide tragovi protjecanja vode, odnosno nazire se korito povremenog podzemnog potoka. Idući dalje kanalom koji se i dalje lagano spušta, a širina kanala opet se poveća na 40-50 m i visina na 10-15 m. Duljina tog kanala je oko 200 m. Krajač ga je je nazvao Perunov trijem.

Iz Perunovog trijema ulazi se u Dvoranu Crne kraljice. I to je samo dio špiljskog kanala, dug oko $200 \mathrm{~m}$, širok 40-50 m i visok 15-20 m. Tlo ove dvorane nalazi se $180 \mathrm{~m}$ ispod razine ulaza. U sjeveroistočnom dijelu kanala (dvorane) odvaja se kanal širine 15 -ak metara prema istoku i spušta za $15 \mathrm{~m}$ pa je za sada to najniža točka špilje. Ivan Krajač ga je nazvao Pakleno. On sam nije se u njega spustio, učinio je to njegov pratilac Mile Sjauš. Krajač je bio samo do $-180 \mathrm{~m}$. tj. na dnu Dvorane Crne kraljice.

Najljepši dio špilje nalazi se na njezinu kraju, a to je brdo koje je Krajač nazvao Troglav ili Troglavovo prijestolje i nalazi se zapadno od Dvorane Crne kraljice. Zapravo je to dvorana veličine oko 120 × $60 \mathrm{~m}$, ali visine $70 \mathrm{~m}$ iznad dna Dvorane crne kraljice. Visina stropa te dvorane, na vrhu Troglava, je 15-ak metara, ali se prema zapadu naglo spušta, pa nastavak špilje čine strme, uske jako zasigane pukotine. Troglavovo prijestolje bogato je raznim sigastim ukrasima ekscentričnog oblika, raznih boja (bijela, žuta, crvena), ali i velikim blokovima kristaliziranog kamenja. 


\section{Posebna istraživanja:}

\section{Speleološka istraživanja}

Prvo speleološko istraživanje obavio je Ivan Krajač 23. srpnja 1930. kada je saznao za špilju. S njim su tada špilju posjetili, odnosno razgledali: Mile Sjauš iz Sjeuševih stanova, Kuzman Zubčić iz Lisarice i seoski glavar iz Ljubotića. Špilju je Krajač posjetio i dvije godine poslije, tj. 24.25. lipnja 1932. Tom je prilikom Krajač špilju mjerio i izradio njezin prvi nacrt. U tome su mu pomagali Mile Sjauš i Josip Geržanić iz Senja. Položaj špilje Krajač je odredio na karti, ali za objavu u časopisu Hrvatski planinar ga nije dao. U članku je samo naveo da je nadmorsku visinu ulaza odredio barometrom (914 m), s pomoću kojega je mjerio i dubinu špilje. Duljine je

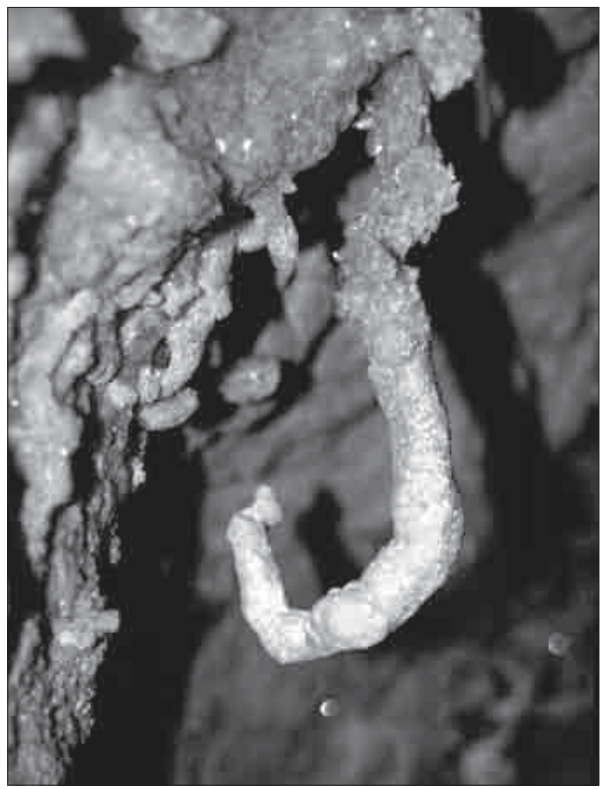

S1. 6. Kuka - jedna od ekscentričnih siga na Troglavovom prijestolju, foto: Vlado Božić, 2000. mjerio mjernom vrpcom. Put si je, kao i njegovi pratioci, osvjetljavao svijećama i ručnim baterijskim svjetiljkama. Detaljno opisujući špilju davao je imena pojedinim, važnijim dijelovima. Naveo je da seljaci koji znaju za špilju, zovu je Jama na Vrtlini, ali ju je on u svom tekstu zvao samo Vrtlina. Ustanovio je da on i njegova pratnja nisu bili prvi koji su posjetili špilju, jer su u Dvorani Crne kraljice, kod mjesta za silaz u Pakleno, našli nekoliko nedogorenih luči i kosti kozoroga. Nekoliko fotografija snimio je na ulaznom dijelu špilje uz pomoć danjeg svjetla. Budući da je do tada već posjetio neke turistički uređene špilje u svijetu uočio je potencijal ove špilje i smišljao mogućnost njezina uređenja za turističke posjete.

Drugo speleološko istraživanje, ujedno i zadnje o kojem je nešto objavljeno, ostvareno je 29.-31. kolovoza 1961. U istraživanju su sudjelovali: Ivica Posarić - Ivčo, vođe ekipe, Vlasta Šegrc - Laca, Drago Pavličević Pavlek, Marija Županić - Mia, Darko Županić i Ivan Filipčić - Filac, svi tada članovi Speleološkog odsjeka Planinarskog društva "Željezničar". Do špilje su putovali preko Like, iz Medka na Štirovac, preko Badnja na Visočicu i odavde do Sjauševih stanova pokraj Vrtline. Samo topografsko snimanje trajalo je dva dana, no do danas je sačuvano samo nekoliko fotografija. Nažalost, opis 
tog istraživanja napisan je i objavljen tek 5 godina kasnije, kada su već mnogi detalji ovih događaja bili zaboravljeni pa nisu zabilježeni. Ipak, tom je prilikom objavljen topografski nacrt koji je najvredniji dokument tog istraživanja.

U posjeti špilji 29.-31. kolovoza 2000. speleolozi su samo obišli do tada istražene dijelove i nisu pronašli nove. Sudjelovali su Milivoj Uroić, Mea Bombardelli, Vladimir Lindić, Goran Lindić, Valerija Lindić i Vlado Božić iz Speleološkog odsjeka HPD "Željezničar" te Mirjana Vrbek i Boris Vrbek iz SO PDS "Velebit".

\section{Biospeleološka istraživanja}

Florističko istraživanje: Jedino florističko (botaničko) istraživanje obavila je botaničarka Mirjana Vrbek, sudjelujući u posjeti špilji 29.-31. kolovoza 2000. Od gornjeg ruba velikog otvora jamskog ulaza u špilju, pa niz strmu kosinu jame i po cijelom siparu do dubine oko $70 \mathrm{~m}$, do koje dubine dopire danje svjetlo, Mirjana je evidentirala 44 biljne svojte. Oko ulaza u špilju je šuma primorske bukve $s$ jesenskom šašikom te po kamenjaru vrisak i vlaska. Gornji dio jamskog ulaza prekriven je manjim drvećem, a donji dio, dugi sipar, zeljastim biljkama među kojima se ističu: Asplenium scolopenarium L, Saxifraga rotundifolia L., Globularia cordifolia L., Daphne alpina L., Viola biflora L., Moehringia muscosa L. Rezultati tog istraživanja objavljeni su tek 10 godina kasnije, na posteru pripremljenom za sudjelovanje na XI. kongresu Hrvatskog tloznanstvenog društva "Perspektive gospodarenja tlom u budućnosti" održanom od 5. do 8. srpnja 2010. na Plitvičkim jezerima. Sažetak je objavljen i u knjizi sažetaka tog skupa na str. 138.

Faunistička istraživanja: Članovi Hrvatskog biospeleološkog društva (HBSD) posjetili su Vrtlinu dva puta, i to za potrebe izrade Atlasa šiljskih tipskih lokaliteta faune Republike Hrvatske. Prvi put su tu boravili 4. kolovoza 2008. i po špilji postavili zamke za hvatanje životinja, a drugi put, dva tjedna poslije, tj. 17. kolovoza 2008. kada su prikupljene, odnosno registrirane dvije svojte tipične za ovu špilju, a to su velebitski endemi, kornjaši Astagobius hadzii, 1973 (velik 5,5 mm) i Leptodirus hochenwarti velebiticus Pretner, 1970 (velik $7 \mathrm{~mm}$ ). Biospeleolozi su u špilji tražili i lažipauka Platybonus spinosissimus o kojem je ranije pisao biolog J. Hadži, ali ga nisu našli. U istraživanju su sudjelovali: Helena Bilandžija, Fanica Kljaković Gašpić i Branko Jalžić.

Špilju su i prije ovih istraživanja posjećivali i naši i strani biospeleolozi, ali o tome nije pisano u hrvatskoj speleološkoj literaturi. Naši, sadašnji biospeleolozi poslužili su se stranom literaturom u traganju za ovim špiljskim endemima. ${ }^{15}$

${ }^{15}$ E PRETNER, 1970, 321-340; J. HADŽI, 1973, 1-120. 
Pedološko istraživanje: Proučavanje tla špilje Vrtline obavio je 2000. godine geolog Boris Vrbek. Uzimao je uzorke tla na vrhu i dnu sipara glavnog ulaza te u špilji na 600 i $800 \mathrm{~m}$ udaljenosti od ulaza. Ustanovio je da se tlo sipara po pedološkoj klasifikaciji sastoji od karbonatnog koluvija s prevagom detritusa stijena i gline, bogat humusom i dušikom, što pogoduje razvoju biljnog pokrova. Uzorci uzeti na 600 i $800 \mathrm{~m}$ od ulaza predstavljaju pravi špiljski sediment, taložen tijekom niza godina. Uočene su razlike u sadržaju humusa, gline i dušika. Rezultati ovog istraživanja objavljeni su na istom posteru na kojem su prikazani rezultati botaničkog istraživanja i prikazan na XI. kongresu Hrvatskog tloznanstvenog društva, održanom 5.-8. lipnja 2010. na Plitvičkim jezerima.

Geološko istraživanje: Proučavanje geologije same špilje još nije obavljeno. Poznato je samo da se okolica ulaza u jamu Vrtlinu sastoji od tzv. vapnenačkih "Jelar breča". Detaljno geološko istraživanje tek predstoji.

Meteorološko istraživanje: Jedini meteorološki podatak objavio je Ivan Krajač 1932. Napisao je da je temperaturu zraka u špilji mjerio na dva-tri mjesta i ustanovio da je jednaka noćnoj temepraturi zraka na površini, i to $10^{\circ} \mathrm{R}$, što odgovara $8^{\circ} \mathrm{C}$.

\section{Turistčki potencijal}

Usporedivši špilju Vrtlinu s njemu poznatim špiljama u Austriji, Češkoj i Sloveniji, Krajač je zaključio da bi i Vrtlinu ljudi posjećivali kada bi se omogućio lakši pristup do nje. Razmišljao je o pješačkom putu od Kruščice i od Visočice, ali i gradnji ceste do blizine špilje i o noćenju u obližnjim Sjeuševim stanovima. Silaz niz ulaznu jamu, smatrao je, treba učiniti "lagano prohodnim" a kroz špilju sagraditi "putić", koji će obići cijelu špilju. Špilju, rekao je, treba opskrbiti električnim svjetlom, koje bi se palilo i osvjetljavalo samo dio špilje kojim se prolazi. Struju za rasvjetu zamislio je dobiti iz dizel agregata. Također je predložio ograditi ulaz, postaviti vrata i naplaćivati ulaz te zaposliti čuvara i vodiča.

Svatko tko je bio u špilji Vrtlini zaželio je da je lakše dostupna, da je lako prohodna i da je bolje osvijetljena. Sve to je danas moguće ostvariti. No, treba najprije riješiti papirologiju. Prema sada prihvaćenim pravilima struke potrebno je najprije izraditi studiju ili stručnu podlogu za izradu projektne i izvedbene dokumentacije. Kako se špilja nalazi na području Parka prirode Velebit studiju ili stručnu podlogu trebao bi zatražiti PP Velebit a izraditi ju udruga kvalificirana za takve poslove, npr. jedna ili više speleoloških udruga zajedno. Projektnu dokumentaciju trebale bi izraditi tvrtke kvalificirane za taj posao. Ovim dokumentima trebalo bi riješiti mnogo toga: 
- osnovati udrugu ili ustanovu koja će organizirati turističke posjete i gospodariti špiljom

- omogućiti lakši pristup do špilje (bolje označiti planinarske staze, sagraditi cestu do blizine špilje)

- osmisliti sadržaj okoliša špilje (prihvatilište posjetitelja, zaštititi jamske ulaze)

- olakšati silazak u špilju (ljestve, stube)

- sagraditi staze kroz špilju

- omogućiti rasvjetu (npr. iz solarnih kolektora, dizel agregata i/ili Scurion svjetiljkama na kacigama)

- organizirati čuvarsku i vodičku službu

Detaljnom razradom navedenih dokumenata treba riješiti još niz sitnih detalja koristeći iskustva domaćih i stranih turističkih špilja. Bilo bi lijepo kada bi se to ostvarilo u bližoj budućnosti.

\section{Literatura}

Jana BEDEK - Sanja GOTTSTEIN MATOČEC - Branko JALŽIĆ - Roman OZIMEC - Vesna ŠTAMOL, Katalog tipskih špiljskih lokaliteta faune Hrvatske, Natura croatica, vol. 15, suppl. 1, Zagreb, 2006.

Mea BOMBARDELLI, Posjet Vrtlini, Speleolog, 48/49, Zagreb, 2003, 78-79.

Vlado BOŽIĆ, Povijest istraživanja i razvoj tehnike svladavanja jama u svijetu i Hrvatskoj, Speleolog, 26/27, Zagreb,1991, 63-74.

Vlado BOŽIĆ, Hrvatski speleološki dubinski rekordi, Hrvatski planinar, 5, Zagreb, 1998, 155.

Vlado BOŽIĆ, Speleologija u Hrvatskoj, Zagreb, 2003, 28-29.

Vlado BOŽIĆ - Hrvoje MALINAR, Razvoj speleološke opreme i tehnike, Zagreb, 2013, 56-58.

Vlado BOŽIĆ, Ilustrirana povijest speleologije u Hrvatskoj, Zagreb, 2014, 35-36.

Alan ČAPLAR, Južni Velebit, Rujno i Bojinac (Vrtlina). Planinarski vodič po Hrvatskoj, Zagreb, 2008, 512.

Jovan HADŽI, Novi taksoni suhih južin (Opilionidea), SAZU, 16/1, Ljubljana, 1973, $1-120$.

Vladimir JAGARIĆ, Ivan Krajač - život $i$ djelo političara, ekonomista, pravnika $i$ planinara, Zagreb, 2009, 85, 159-160.

Branko JALŽIĆ - Jana BEDEK - Helena BILANDŽIJA - Hrvoje CVITANOVIĆ Tvrtko DRAŽINA - Sanja GOTTSTEIN - Fanica KLJAKOVIĆ GAŠPIĆ Marko LUKIĆ - Roman OZIMEC - Martina PAVLEK - Rajko SLAPNIK Vesna ŠTAMOL, Vrtlina jama, Atlas špiljskih tipskih lokaliteta faune Republike Hrvatske, Zagreb, 2010, 14, 225, 226, 227, 249. 
Ivan KRAJAČ, Vrtlina, nova ogromna spilja u Velebitu, Hrvatski planinar, 9, Zagreb, 1932, 268-278.

Drago PAVLIČEVIĆ, Jama Vrtlina na Velebitu, Naše planine, 3-4, Zagreb, 1966, 61-63.

Željko POLJAK, Južni Velebit, uzdužna staza po primorskoj terasi (Vrtlina), Planine Hrvatske, Zagreb, 1981, 423.

Željko POLJAK, Južni Velebit, uzdužna staza po primorskoj padini (Vrtlina), Hrvatske planine, Zagreb, 1998, 401.

Željko POLJAK, Južni Velebit, dionica Jelova Ruja - Stap (Vrtlina), Hrvatske planine, Zagreb, 2001, 456.

Slavko TOMERLIN, Osiguran silaz u jamu Vrtlinu, Naše planine, 1-2, Zagreb, 1987, 43

Mirjana VRBEK - Boris VRBEK, Florističko pedološke osobitosti ulaznog dijela speleološkog objekta Vrtlina na južnom Velebitu, XI. Kongres Hrvatskog tloznanstvenog društva, Perspektive gospodarenja tlom u budućnosti, Nacionalni park Plitvička jezera 5.-8. srpnja 2010., knjiga sažetaka, 138.

\section{VRTLINA - THE HUGE CAVE OF VELEBIT PODGORJE}

Summary

At the far south of Velebit Podgorje, between Visočica and Kruščica, in the area of the Velebit Nature Park, there is a cave with four pit entrances. From the main, largest entrance opening $(40 \times 50 \mathrm{~m})$, which makes a pit about $70 \mathrm{~m}$ deep the cave extends in a northwest direction, almost rectilinear, about $900 \mathrm{~m}$ long and $195 \mathrm{~m}$ deep. The width of the cave channel is 20-80 m, which makes it especially interesting. The first person to explore, describe and draw a plan of it was Ivan Krajač from Senj in 1932, and speleologists from Zagreb continued the work. During an exploration of Velebit in 1961 the speleologists from Zagreb once again explored the cave and recorded it topographically. One independent study was carried out by Jerko Malinar (Speleological Section of the Velebit Mountaineering Society University from Zagreb) in 1978 and somewhere towards the end of the cave he found a new channel with a syphon lake, but he did not photograph it. One team of Zagreb speleologists visited Vrtlina in 2000 to take photographs, and along the way they looked for new sections, however, Malinar's channel was not found. In 1987 Zadar mountaineer Slavko Tomerlin installed (with the help of speleologists) a steel cable for support during the descent down the steep wall of the pit, 40 or so metres deep (to the top of the rock creep). Mountaineers and speleologists have also visited the cave, and in recent years, biospeleologists have also visited it many times, studying the flora at the entrance part of the cave and the fauna of the interior of the cave. The greatest features of the cave are the huge underground spaces with enormous stone blocks that have fallen from the ceiling as well as the beautiful cave decorations (flowstones, stalagmites and stalactites in various colours, plus eccentric dripstones with large visible crystals). Even back in 1932 Ivan Krajač suggested that the cave be adapted for tourism, which is still a suggestion today when there exist many greater technical possibilities for it.

Keywords: Podgorje, cave, exploration, spatiality, tourism 